Article

\title{
Dissolved Metal(loid) Concentrations and Their Relations with Chromophoric and Fluorescent Dissolved Organic Matter in an Urban River in Shenzhen, South China
}

\author{
Song Zhang ${ }^{1}$, Xun-Wen Chen ${ }^{2,3}$, Quanhui Ye ${ }^{2,3}$, Zi-Ting Zhang ${ }^{2,3}$, Si-Fang Kong ${ }^{4}$, Chun Cao ${ }^{1, *}$ \\ and Jun-Jian Wang $2,3, *$ (D) \\ 1 College of Geography and Environmental Science, Northwest Normal University, Lanzhou 730070, China; \\ 13527333153@163.com \\ 2 Guangdong Provincial Key Laboratory of Soil and Groundwater Pollution Control, School of Environmental \\ Science and Engineering, Southern University of Science and Technology, Shenzhen 518055, China; \\ chenxw3@sustech.edu.cn (X.-W.C.); qye2@nd.edu (Q.Y.); 11849171@mail.sustech.edu.cn (Z.-T.Z.) \\ 3 State Environmental Protection Key Laboratory of Integrated Surface Water Groundwater Pollution Control, \\ School of Environmental Science and Engineering, Southern University of Science and Technology, \\ Shenzhen 518055, China \\ 4 School of Traffic \& Environment, Shenzhen Institute of Information Technology, Shenzhen 518172, China; \\ mengsiksf@163.com \\ * Correspondence: caochun1978@163.com (C.C.); wangjj@sustech.edu.cn (J.-J.W.)
}

Received: 21 December 2019; Accepted: 16 January 2020; Published: 18 January 2020

\begin{abstract}
Urbanization is often accompanied by aquatic metal(loid) pollution, which is regulated by dissolved organic matter (DOM). However, the relationships between dissolved metal(loid) concentration and the bulk, chromophoric, and fluorescent DOM in black and odorous urban rivers are still poorly understood. Here, we investigated the dissolved metal(loid) concentrations of $\mathrm{Zn}$, $\mathrm{Cu}, \mathrm{Cr}, \mathrm{As}, \mathrm{Pb}$, and $\mathrm{Cd}$ and their correlations with DOM-related parameters in water samples from a polluted urbanized watershed in Shenzhen, China. The results showed that the $\mathrm{Zn}$ and $\mathrm{Cu}$ concentrations in the mainstream and tributary exceeded the national standards, and the wastewater treatment plant (WWTP) was an important source, as indicated by the abrupt concentration increases downstream of the WWTP. The dissolved metal(loid) concentrations were not always significantly correlated with the dissolved organic carbon (DOC) concentration or the ultraviolet absorbance at $254 \mathrm{~nm}\left(\mathrm{UV}_{254}\right)$; however, they were more likely to be correlated with the maximum fluorescence intensity (Fmax) of protein-like fluorescent DOM components. A strong correlation between the $\mathrm{Cu} / \mathrm{DOC}$ ratio and specific $\mathrm{UV}_{254}\left(\mathrm{SUVA}_{254}\right)$ previously reported did not exist in the present study. Instead, the $\mathrm{Cu} / \mathrm{DOC}$ ratio was positively correlated with the Fmax/DOC ratios for protein-like fluorescent DOM components. Our study highlights that protein-like fluorescent DOM may be more important than humic-like fluorescence DOM and chromophoric DOM in terms of interacting with dissolved metal(loid)s in black and odorous urban rivers.
\end{abstract}

Keywords: dissolved metal(loid)s; dissolved organic matter; correlation analyses; spectroscopic characteristics; urbanized rivers

\section{Introduction}

Dissolved metal(loid) contamination in rivers raises serious concerns worldwide due to the potential toxicity and ecosystem risks [1-3]. Concentrations of these elements are influenced by both natural and anthropogenic factors, such as parent rock weathering, mining, industrial and domestic 
discharge, and landscape changes [4-6]. Compared to those in particulate form, metal(loid)s in dissolved form are highly bioavailable and can be accumulated by organisms more easily, thereby causing high biological toxicity and threats to ecosystems and human health [7,8]. In urbanized areas, river water quality, in terms of dissolved metal(loid)s, tends to be increasingly disturbed by intensive human activities, such as discharges from untreated and treated industrial and domestic wastewater $[7,9]$.

The ubiquitous dissolved organic matter (DOM) in aquatic environments is a highly heterogeneous mixture and plays an important role in several processes, such as chelation, solution, precipitation, and bioaccumulation of dissolved metal(loid)s $[10,11]$. These roles of DOM are often associated with the chemical structure and properties of the DOM [11-13]. DOM from different sources may have various amounts of O-containing functional groups (e.g., carboxylic and phenolic groups) and Nand S-containing functional groups (e.g., amide and thiol groups) [14]. These groups can have a strong affinity for dissolved metal(loid)s; thus, they can affect the metal(loid)-DOM complexation and metal(loid) behavior in the environment [15-17].

The relationships between dissolved metal(loid)s and DOM have been investigated in various aquatic environments [18-20]. The specific ultraviolet absorbance at $254 \mathrm{~nm}\left(\mathrm{SUVA}_{254}\right)$, which represents the aromatic structure of DOM, is often positively correlated with metal(loid) affinity [15,18,21,22]. DOM with a greater molecular weight usually possesses a higher binding ability to $\mathrm{Cu}$ and $\mathrm{Hg}$ ions; however, this relationship also depends on the DOM sources (terrestrial versus aquatic sources) and DOM degradation processes [22,23]. Different metal(loid)s interact with DOM in different ways [11]. For example, the d-block element, $\mathrm{Cu}$, can be strongly bound to the phenolic (at $\mathrm{pH}$ of 4-8) and carboxyl groups (at $\mathrm{pH}<7$ ) as well as to the amine-containing sites on low-molecular-weight and less aromatic molecules $[24,25]$. In contrast, the p-block element, $\mathrm{Pb}$, can be bound to the phenols, alcohols, ether, and larger molecules, but forms weaker bonds with the carboxyl group [25].

With fast urbanization in recent decades, more than 2000 black and odorous rivers have formed in China [26]. While many studies have been performed on DOM-metal(loid) interactions in natural water [10,27], the understanding of DOM-metal(loid) interactions in black and odorous rivers is relatively limited. In particular, the DOM from urban regions often has complex sources and characteristics and is distinct from that in natural water [28,29]. Because the metal-binding constant of DOM depends on the DOM origin [22], the observed relationships between DOM and metals in natural water could not be generalized for water subjected to intensive human disturbance. In addition, various anthropogenic sources of metal(loid)s, such as industrial and domestic wastewater discharge and urban runoff $[30,31]$, may further complicate the metal(loid) composition and distribution and alter the metal(loid)-DOM equilibrium. Urbanization significantly influences DOM characteristics, such as composition, aromaticity, molecular size, and functional groups [28,29,32,33], which inevitably alter metal(loid) affinity [15]. For example, while the DOM in a peri-urban river exhibited significant positive correlations with $\mathrm{Mn}, \mathrm{Pb}$, and $\mathrm{Cu}$, the $\mathrm{DOM}$ in an urban river had significantly positive correlations with $\mathrm{Cr}, \mathrm{Mn}, \mathrm{As}, \mathrm{Zn}$, and $\mathrm{Pb}$ [34]. While a limited number of studies have investigated the relations between dissolved metals and chromophoric DOM (CDOM) in urban rivers, the correlations between dissolved metal(loid) levels and DOM abundance and characteristics in black and odorous urban rivers are still poorly understood.

Shenzhen is a city with the fastest urbanization rate in China in recent decades, and its Maozhou River is one of the most polluted black and odorous rivers in South China [35-37]. Using the Maozhou River watershed as an example, the present study investigated the concentration levels of dissolved metal(loid)s and their correlations with the abundances of bulk DOM, CDOM, and fluorescent dissolved organic matter (FDOM) in different water types. The objectives were to (a) investigate the impact of rapid urbanization on the concentration levels and spatial distribution of dissolved metal(loid)s in this highly polluted urban watershed, and (b) identify the critical DOM parameters linked with the dissolved metal(loid) levels 


\section{Materials and Methods}

\subsection{Site Description}

Shenzhen, an emerging international metropolis with an area of $1997 \mathrm{~km}^{2}$, is located in the southern region of Guangdong Province of China and is adjacent to the South China Sea [35-37]. With rapid urbanization and economic development in the past four decades, the city has grown to be one of the most prosperous cities in China [35]. The Maozhou River is the largest river in Shenzhen. The Maozhou River watershed has an area of $388.23 \mathrm{~km}^{2}$, and $52.1 \%$ of this watershed is composed of residential and industrial areas. One-third of the Shenzhen population (i.e., 3.7 million) lives in the Maozhou River watershed [28]. The mainstream originates from the Yangtai Mountain and has a length of approximately $42 \mathrm{~km}$. The water in the river finally enters into the Pearl River Estuary (Figure 1). The mean annual temperature within the Maozhou River watershed is $22.3^{\circ} \mathrm{C}$ and the mean annual precipitation is $1606 \mathrm{~mm}$, with $80 \%$ of the rainfall occurring from April to September [38]. A number of electroplating and dyeing factories have been established along the river. Both domesticand industrial-treated wastewaters are discharged into the river, and a wastewater treatment plant (WWTP) that handles 110,000 $\mathrm{m}^{3}$ of domestic wastewater and 30,000 $\mathrm{m}^{3}$ of industrial wastewater per day is located at the M9 sampling site [26].

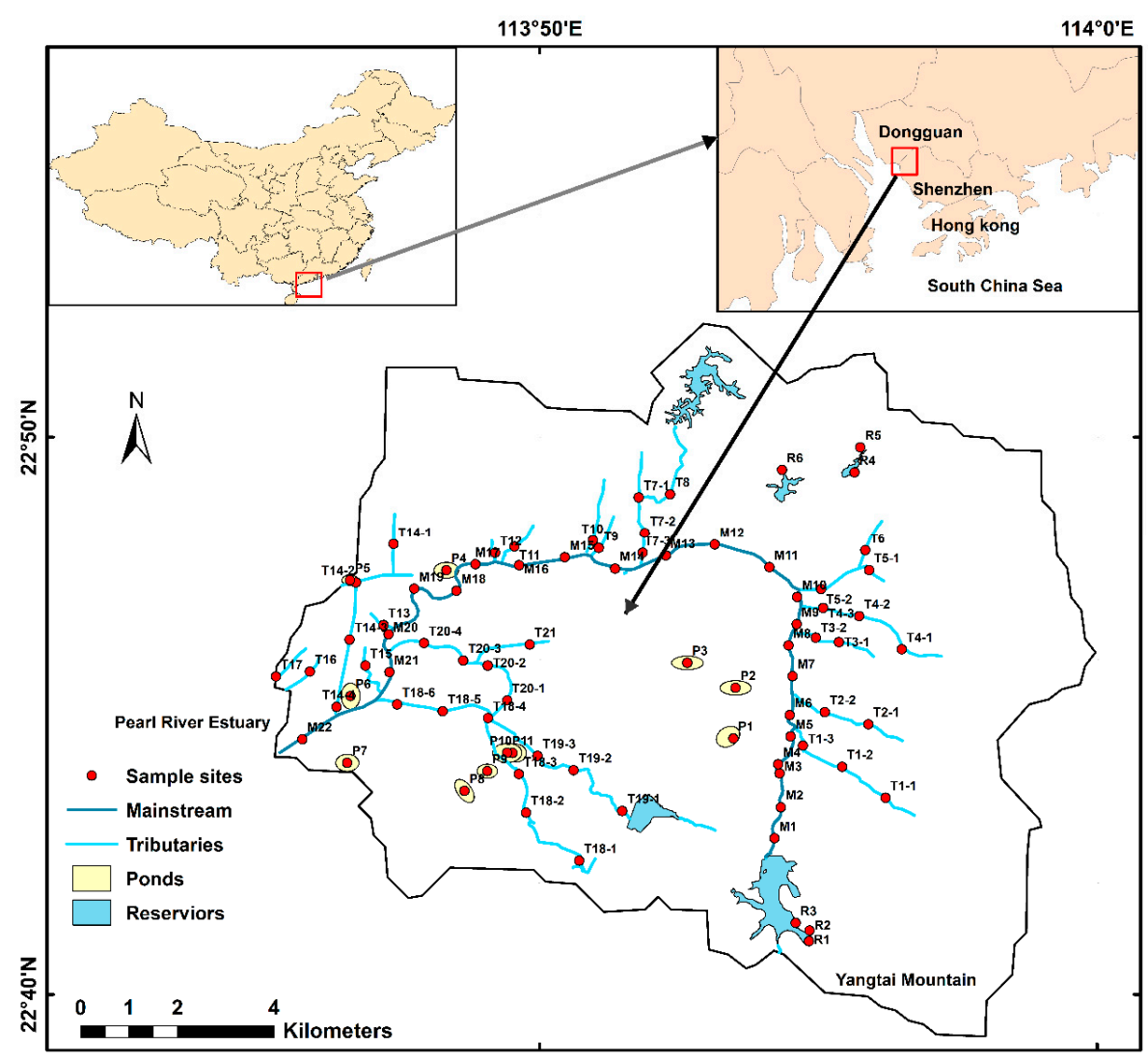

Figure 1. Sampling sites within the Maozhou River watershed in Shenzhen, China.

\subsection{Sample Collection}

As the dry season usually had higher dissolved metal(loid) concentrations without rainwater dilution, we collected samples in the dry season to understand the maximum ecological risks of the dissolved metal(loid)s in the Maozhou River. In total, 84 surface water samples were collected at the Maozhou River watershed in January 2019, including 22 from the mainstream (from upstream to downstream, M1 to M22), 43 from the tributaries (T1 to T21), 11 from the ponds (P1 to P11), and 6 from the reservoirs (R1 to R6) (Figure 1). All washed bottles were rinsed with the water samples three 
times before sample collection. For each sampling point, a composite sample was collected by mixing two water samples. All samples were sent to the laboratory at low temperature, immediately filtered through Whatman GF/F $0.7 \mu \mathrm{m}$ glass fiber filters (pre-combusted at $450{ }^{\circ} \mathrm{C}$ for $4.5 \mathrm{~h}$ ), and stored at $4{ }^{\circ} \mathrm{C}$ before further processing.

\subsection{Chemical Analyses}

For all samples, $\mathrm{pH}$ and electrical conductivity (EC) were measured using a HACH HQ440d benchtop instrument (equipped with an Intellical ${ }^{\mathrm{TM}}$ PHC201 probe and a CDC401 probe). The concentrations of dissolved organic carbon (DOC) were analyzed using a total organic carbon (TOC) analyzer (Shimadzu, Kyoto, Japan) with an ASI-L autosampler. To remove inorganic carbon from the water sample, samples were acidified using hydrochloric acid before DOC analysis.

Before analysis of dissolved metal(loid) concentrations, $10 \mathrm{~mL}$ of the filtered sample was acidified with $200 \mu \mathrm{L}$ concentrated nitric acid (electronic grade, Aladdin). The concentrations of total dissolved metal(loid)s in the water sample were measured by inductively coupled plasma mass spectrometry (ICP-MS, Thermo Fisher Scientific, Boston, MA, USA). Six dissolved metal(loid)s, including Cu, Zn, Cr, $\mathrm{As}, \mathrm{Cd}$, and $\mathrm{Pb}$, were quantified. For quality assurance and quality control, each sample was detected at least three times, and an average value was calculated. Blanks resulting from the same preparation procedures and standard solutions were used in every ten samples during the analysis. The water used in the entire experiment was Milli-Q water $\left(18.2 \mathrm{M} \Omega \mathrm{cm}, 25^{\circ} \mathrm{C}\right)$ and all containers were acid washed before use. The recoveries of metal(loid)s were between $80 \%-100 \%$, and the detection limits were in the range of $0.01-0.05 \mu \mathrm{g} / \mathrm{L}$ depending on the metal(loid) species. The metal(loid)-to-DOC concentration ratios (Me/DOC) were also calculated and linked with the spectroscopic characteristics of the DOM. Among these Me/DOC ratios, the $\mathrm{Cu} / \mathrm{DOC}$ ratio has been shown to be an excellent proxy for the ratio of DOM-bound $\mathrm{Cu}$ to DOC concentrations in urban rivers [18]. In addition, the Nemero synthetic pollution index $\left(P_{\text {syn }}\right)$ of each sampled water was calculated as follows [39]:

$$
\begin{gathered}
P_{\text {syn }}=\left\{\left[\left(P_{i}\right)_{\text {max }}^{2}+\left(P_{i}\right)_{\text {average }}^{2}\right] / 2\right\}^{1 / 2} \\
P_{\mathrm{i}}=C_{\mathrm{i}} / S_{\mathrm{i}}
\end{gathered}
$$

where $P_{i}$ is the individual pollution index, $i$ is the order of different metal(loid) species, $C_{\mathrm{i}}$ is the concentration of the $i$-th metal(loid), and $S_{\mathrm{i}}$ is the reference value of the $i$-th metal. Here, the evaluation criterion, $S_{i}$, is based on the National Environmental Standard for Surface Water Quality (GB 3838-2002, Class I; Ministry of Ecology and Environment of China, 2002). Water is considered "nonpolluted" when $P_{\text {syn }} \leq 1$, "slightly polluted" when $1<P_{\text {syn }} \leq 2$, and "polluted" when $P_{\text {syn }}>2$.

The absorption and fluorescence spectroscopic analyses are fast, low-cost, and sensitive approaches that can be used to characterize the aromaticity, molecular size, source, and composition of DOM in aquatic environments [40]. The ultraviolet-visible spectra and fluorescent excitation-emission matrices (EEMs) of water samples were analyzed by an absorption and fluorescence spectrometer (Aqualog, Horiba, Kyoto, Japan) at room temperature, as described in our recent study [28]. A series of indices were obtained, including ultraviolet absorbance at $254 \mathrm{~nm}\left(\mathrm{UV}_{254}\right)$, maximum fluorescence intensities for four resolved fluorescent DOM components $i$ (noted as Fmax ${ }_{\mathrm{Ci}}$ ) based on parallel factor analysis (PARAFAC), special ultraviolet absorbance at $254 \mathrm{~nm}\left(\mathrm{SUVA}_{254}\right)$, spectral slope of 275-295 nm region $\left(\mathrm{S}_{275-295}\right)$, humification index (HIX), and biological index (BIX). The $\mathrm{UV}_{254}$ value was obtained to indicate the abundance of CDOM, and the Fmax $\mathrm{Ci}_{\mathrm{i}}$ values were used to reflect the abundances of FDOM. The four fluorescent components resolved by PARAFAC were as follows: $\mathrm{C} 1$, terrestrially-derived humic-like component, C2, reprocessed terrestrially-derived humic-like component, C3, tyrosine-like component, and C4, tryptophan-like component (Supplementary Figure S1 and Table S1). Generally, while the tyrosine-like component originated from the products of algae and microorganisms [41], the tryptophan-like component was detected in urban rivers or streams polluted by wastewater [42]. The Fmax/DOC ratio for component $i$ (denoted as Fmax/DOC $\mathrm{Ci}_{\text {) }}$ ) was also calculated to indicate the 
abundances of various types of FDOM in DOM [43]. While a high $\mathrm{SUVA}_{254}$ is an indicator of high DOM aromaticity [44], a high $\mathrm{S}_{275-295}$ is usually indicative of low molecular weight of the DOM [45]. The HIX usually reflects the degree of humification of the sample, and a higher HIX value indicates a lower $\mathrm{H} / \mathrm{C}$ and more ring structures [46]. The BIX was related to the contribution of freshly produced DOM in the water samples [47]. Values of BIX between 0.8 and 1.0 correspond to freshly produced DOM of biological or microbial origin, while values below 0.6 are considered to contain little autochthonous organic matter [42].

\subsection{Data Analysis}

The watershed-scale spatial distributions of six dissolved metal(loid) concentrations were plotted using ArcGIS 10.5. The differences in water quality, metal(loid) concentrations, and DOM-related parameters among water types (mainstream, tributary, pond, and reservoir samples) were analyzed by analysis of variance (ANOVA) and Tukey's honestly significant difference (HSD) test after logarithmic transformation of the non-normal data. As the Kaiser-Meyer-Olkin and Bartlett tests were satisfied, principal component analysis (PCA) was applied for data reduction of the dissolved metal(loid) concentrations in the mainstream and tributary river samples. The loading of metal(loid)s and score of each sample were obtained. Spearman's correlation analyses were applied to explore the relations between the dissolved metal(loid) concentrations and the abundances of bulk DOM (DOC concentration), CDOM $\left(\mathrm{UV}_{254}\right)$, and FDOM $\left(\right.$ Fmax $\left._{\mathrm{Ci}}\right)$, and between the Me/DOC ratio and DOM characteristics, including $\mathrm{SUVA}_{254}, \mathrm{~S}_{275-295}$, HIX, BIX, and Fmax/DOC $\mathrm{Ci}$. Correlation analyses were conducted for three sample categories, i.e., (1) all samples, (2) more disturbed mainstream and tributary samples, and (3) less disturbed pond and reservoir samples. The significance level was set at $p<0.05$.

\section{Results}

\subsection{Spatial Variations in Water Quality and Dissolved Metal(loid) Concentrations}

The $\mathrm{pH}$ values of the mainstream (mean \pm standard deviation (SD), $7.35 \pm 0.21$ ), tributary $(7.69 \pm 0.50)$, and reservoir $(7.33 \pm 0.14)$ samples were similar, while the $\mathrm{pH}$ of the pond samples was $8.25 \pm 0.30$ (Table 1). The average EC values of the mainstream $\left(2.00 \mathrm{mS} \cdot \mathrm{m}^{-1}\right)$, tributary $\left(3.06 \mathrm{mS} \cdot \mathrm{m}^{-1}\right)$, and pond samples $\left(0.76 \mathrm{mS} \cdot \mathrm{m}^{-1}\right)$ were 22,34 , and 8 times higher than those of the reservoirs $\left(0.09 \mathrm{mS} \cdot \mathrm{m}^{-1}\right)$, respectively (Table 1$)$. Within the mainstream, there was a sharp increase in EC, from $0.56 \mathrm{mS} \cdot \mathrm{m}^{-1}$ at M8 to $1.07 \mathrm{mS} \cdot \mathrm{m}^{-1}$ at M9 (Supplementary Figure S2). Affected by seawater intrusion, sites M20-M22 had EC values higher than $5 \mathrm{mS} \cdot \mathrm{m}^{-1}$.

For the mainstream water, the dissolved metal(loid) concentrations (in $\mu \mathrm{g} \cdot \mathrm{L}^{-1}$ ) were $64.01 \pm 43.31$ for $\mathrm{Zn}, 6.33 \pm 3.94$ for $\mathrm{Cu}, 1.48 \pm 0.9$ for $\mathrm{Cr}, 1.24 \pm 0.37$ for $\mathrm{As}, 0.32 \pm 0.28$ for $\mathrm{Pb}$, and $0.14 \pm 0.15$ for $\mathrm{Cd}(\mathrm{n}=22$; Table 1 and Figure 2). Additionally, 22.7\% of the $\mathrm{Zn}$ concentrations and $45.5 \%$ of the $\mathrm{Cu}$ concentrations exceeded the Class I threshold value of the National Environmental Standard for Surface Water Quality ("national standards" hereafter) [48], and Zn had an average $P_{\mathrm{i}}$ value greater than 1 (Supplementary Table S1). For the tributary water, the dissolved metal(loid) concentrations (in $\mu \mathrm{g} \cdot \mathrm{L}^{-1}$ ) were $41.56 \pm 53.12$ for $\mathrm{Zn}, 13.49 \pm 38.68$ for $\mathrm{Cu}, 2.96 \pm 4.87$ for $\mathrm{Cr}, 1.47 \pm 0.62$ for As, $0.38 \pm 0.32$ for $\mathrm{Pb}$, and $0.11 \pm 0.13$ for $\mathrm{Cd}$. Additionally, $30.2 \%$ of the $\mathrm{Zn}$ concentrations and $18.6 \%$ of the $\mathrm{Cu}$ concentrations exceeded the national standards, and $\mathrm{Zn}$ had an average $P_{\mathrm{i}}$ value greater than 1 (Table 1). Almost all average dissolved metal(loid) concentrations in the ponds and reservoirs were much lower than those in the mainstream and tributaries of the Maozhou River; however, the ponds had a slightly higher As concentration than did the mainstream or tributaries (Table 1). All dissolved metal(loid) concentrations in ponds and reservoirs were below the national standards and thus had $P_{\mathrm{i}}$ values below 1. Based on the metal(loid) concentrations, the average synthetic pollution indices $\left(P_{\text {syn }}\right)$ for different water types were obtained and followed the order of tributary (1.22) > mainstream $(0.63)$ $>$ pond (0.17) > reservoir (0.14). 
The mainstream sites were further divided into three groups: upper (M1-M7), middle (M8-M16), and lower (M17-M22) mainstream. None of the dissolved metal(loid) concentrations in the upper mainstream exceeded the national standards (Supplementary Figure S3), and the average $P_{\text {syn }}$ value in upper mainstream was 0.54 (Table 2). All six metal(loid)s had sharp concentration increases from the upper to the middle mainstream (from M7 to M9; Figure 3 and Supplementary Figure S3). All samples in the middle mainstream had $\mathrm{Zn}$ concentrations higher than the national standard, and one-third of them had $\mathrm{Cu}$ concentrations higher than the national standard, which resulted in a high average $P_{\text {syn }}$ value of 1.67 in the middle mainstream (Table 2). Most of the metal(loid) concentrations showed decreasing trends in the middle mainstream from M8 or M9 to M16 (Supplementary Figure S3). In the lower mainstream, which had a $P_{\text {syn }}$ value of 0.97 , the dissolved metal(loid) concentrations had high fluctuations and were higher than the national standards at three sites, M17 (for Zn), M18 (for Cu and $\mathrm{Zn}$ ), and M22 (for $\mathrm{Cu}$ ). The PCA results showed that, in the mainstream, the accumulated variance of the first (PC1) and second (PC2) principal components explained $67.60 \%$ of the total variance (Figure 4 ). $\mathrm{PC} 1(39.20 \%$ of total variance) was dominated by the loadings from $\mathrm{Cd}, \mathrm{Pb}, \mathrm{Cu}$, and $\mathrm{Zn}$, while PC2 ( $28.40 \%$ of total variance) had high loadings from $\mathrm{Cr}$ and As (Figure 4a). M1 to M7 appeared in the lower-left corner of the score plot and showed low scores on both PC1 and PC2, while M9-M13 had higher scores on PC1 (Figure 4b). The M14-M22 sites were clustered and showed high scores on PC2 (Figure $4 b$ ).
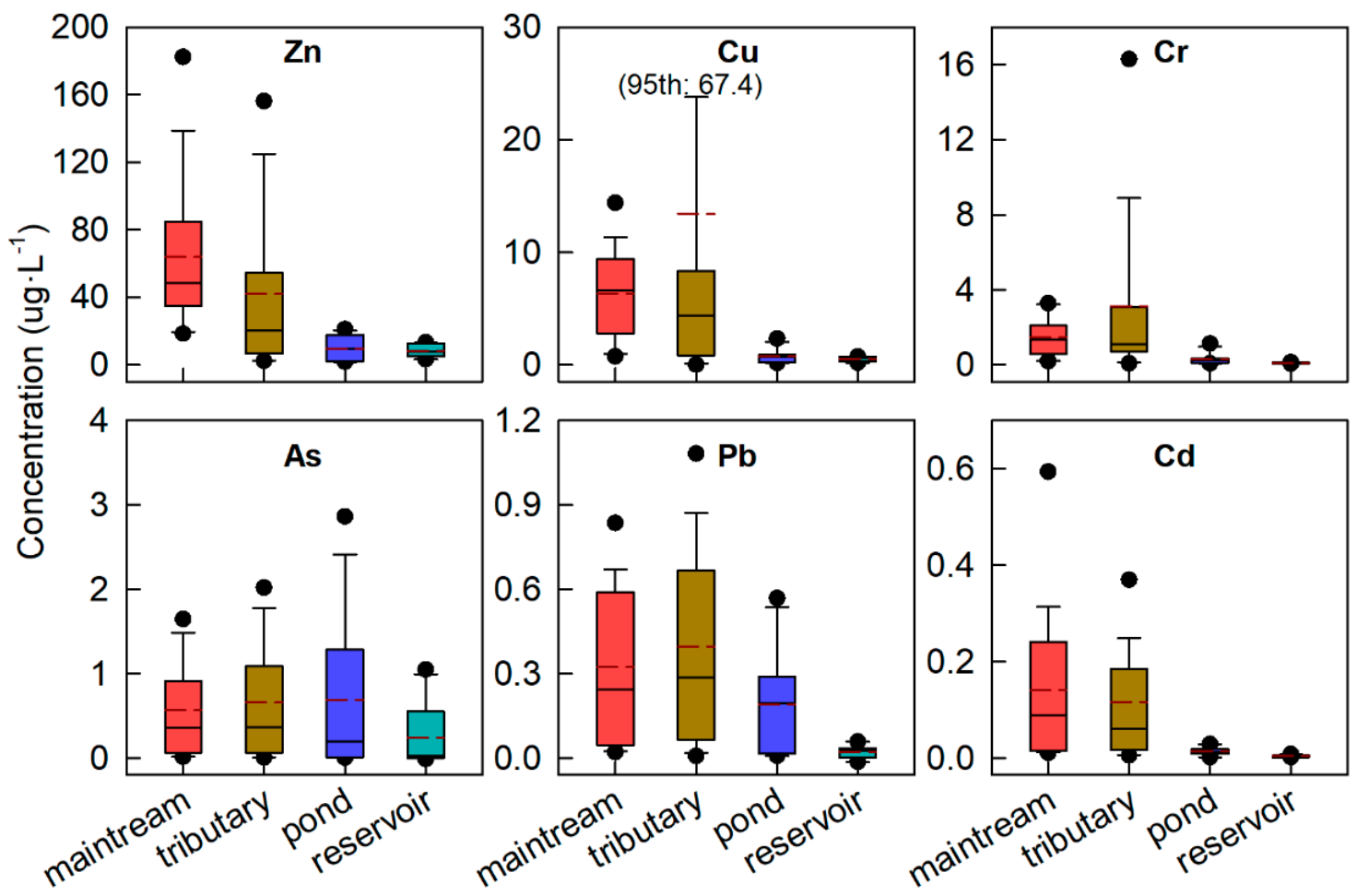

Figure 2. Dissolved metal(loid) concentrations of different water types in the Maozhou River watershed in Shenzhen, China. The boxplots show the 5th, 10th, 25th, 50th, 75th, 90th, and 95th percentiles of the data; the red dashed lines indicate the average values. 
Table 1. General water quality and dissolved metal(loid) concentrations for different water types in the Maozhou River watershed and previously reported urbanized rivers.

\begin{tabular}{|c|c|c|c|c|c|c|c|c|c|c|c|}
\hline & Water Type & $\mathbf{n}$ & $\mathrm{pH}$ & $\begin{array}{c}\text { EC } \\
\left(\mathrm{mS} \cdot \mathrm{m}^{-1}\right)\end{array}$ & $\mathrm{Zn}\left(\mu \mathrm{g} \cdot \mathrm{L}^{-1}\right)$ & $\mathrm{Cu}\left(\mu \mathrm{g} \cdot \mathrm{L}^{-1}\right)$ & $\mathrm{Cr}\left(\mu \mathrm{g} \cdot \mathrm{L}^{-1}\right)$ & $\begin{array}{c}\text { As } \\
\left(\mu \mathrm{g} \cdot \mathrm{L}^{-1}\right)\end{array}$ & $\begin{array}{c}\mathrm{Pb} \\
\left(\mu \mathrm{g} \cdot \mathrm{L}^{-1}\right)\end{array}$ & $\begin{array}{c}C d \\
\left(\mu \mathrm{g} \cdot \mathrm{L}^{-1}\right)\end{array}$ & Reference \\
\hline \multirow{4}{*}{ Maozhou River, Shenzhen (China) } & Mainstream & 22 & $7.35 \pm 0.21$ & $2.00 \pm 3.38$ & $64.01 \pm 43.31$ & $6.33 \pm 3.94$ & $1.48 \pm 0.97$ & $1.24 \pm 0.37$ & $0.32 \pm 0.28$ & $0.14 \pm 0.15$ & \multirow{4}{*}{ this study } \\
\hline & Tributary & 43 & $7.69 \pm 0.50$ & $3.06 \pm 4.97$ & $41.56 \pm 53.12$ & $13.49 \pm 38.68$ & $2.96 \pm 4.87$ & $1.47 \pm 0.62$ & $0.38 \pm 0.32$ & $0.11 \pm 0.13$ & \\
\hline & Pond & 11 & $8.25 \pm 0.30$ & $0.76 \pm 0.50$ & $9.58 \pm 6.75$ & $0.74 \pm 0.57$ & $0.29 \pm 0.28$ & $1.87 \pm 0.81$ & $0.19 \pm 0.17$ & $0.01 \pm 0.01$ & \\
\hline & Reservoir & 6 & $7.33 \pm 0.14$ & $0.09 \pm 0.03$ & $8.38 \pm 3.03$ & $0.53 \pm 0.20$ & $0.10 \pm 0.02$ & $0.69 \pm 0.23$ & $0.02 \pm 0.02$ & $<0.01$ & \\
\hline Ctalamochita River (Argentina) & River water & 30 & 8.5 & 3.74 & 32.3 & 12.7 & 12.7 & 45.5 & 5.6 & - & [49] \\
\hline Goksu Stream (Turkey) & River water & 18 & - & - & - & 4.69 & 0.80 & 6.86 & - & - & [50] \\
\hline Sagami River (Japan) & River water & 92 & $6.4-9.4$ & - & 1.27 & 0.81 & - & - & - & - & [18] \\
\hline Korotoa River (Bangladesh) & River water & 10 & - & - & 73 & - & 83 & 46 & 11 & 35 & [51] \\
\hline Orge River (France) & River water & 32 & - & - & 1.6 & 62 & 0.68 & - & - & 0.17 & [52] \\
\hline Han River (China) & River water & 42 & - & - & - & 13.35 & 8.14 & 14.2 & 9.26 & 2.31 & [53] \\
\hline National standards (China) ${ }^{a}$ & & & & & 50 & 10 & 10 & 50 & 10 & 1 & \\
\hline
\end{tabular}

the National Environmental Standard for Surface Water Quality (GB 3838-2002). 
Table 2. Pollution indices of dissolved metal(loid)s in four types of water in Maozhou River watershed.

\begin{tabular}{ccccccccc}
\hline \multirow{2}{*}{ Water Type } & \multicolumn{7}{c}{ Single Factor Index Method $\left(\boldsymbol{P}_{\boldsymbol{i}}\right)$} & Synthetic Pollution \\
\cline { 2 - 8 } & & $\mathbf{Z n}$ & $\mathbf{C u}$ & $\mathbf{C r}$ & $\mathbf{A s}$ & $\mathbf{P b}$ & $\mathbf{C d}$ & Index $\left(\boldsymbol{P}_{\text {syn }}\right)$ \\
\hline \multirow{3}{*}{ Mainstream } & upper & 0.658 & 0.173 & 0.063 & 0.018 & 0.004 & 0.014 & 0.54 \\
& middle & 1.962 & 0.828 & 0.142 & 0.024 & 0.055 & 0.212 & 1.67 \\
& lower & 0.982 & 0.877 & 0.254 & 0.034 & 0.032 & 0.182 & 0.97 \\
& overall & 1.201 & 0.626 & 0.153 & 0.025 & 0.030 & 0.136 & 0.63 \\
Tributary & & 0.831 & 1.350 & 0.300 & 0.030 & 0.038 & 0.112 & 1.22 \\
Pond & & 0.192 & 0.074 & 0.029 & 0.037 & 0.019 & 0.014 & 0.17 \\
Reservoir & & 0.168 & 0.052 & 0.010 & 0.014 & 0.002 & 0.004 & 0.14 \\
\hline
\end{tabular}

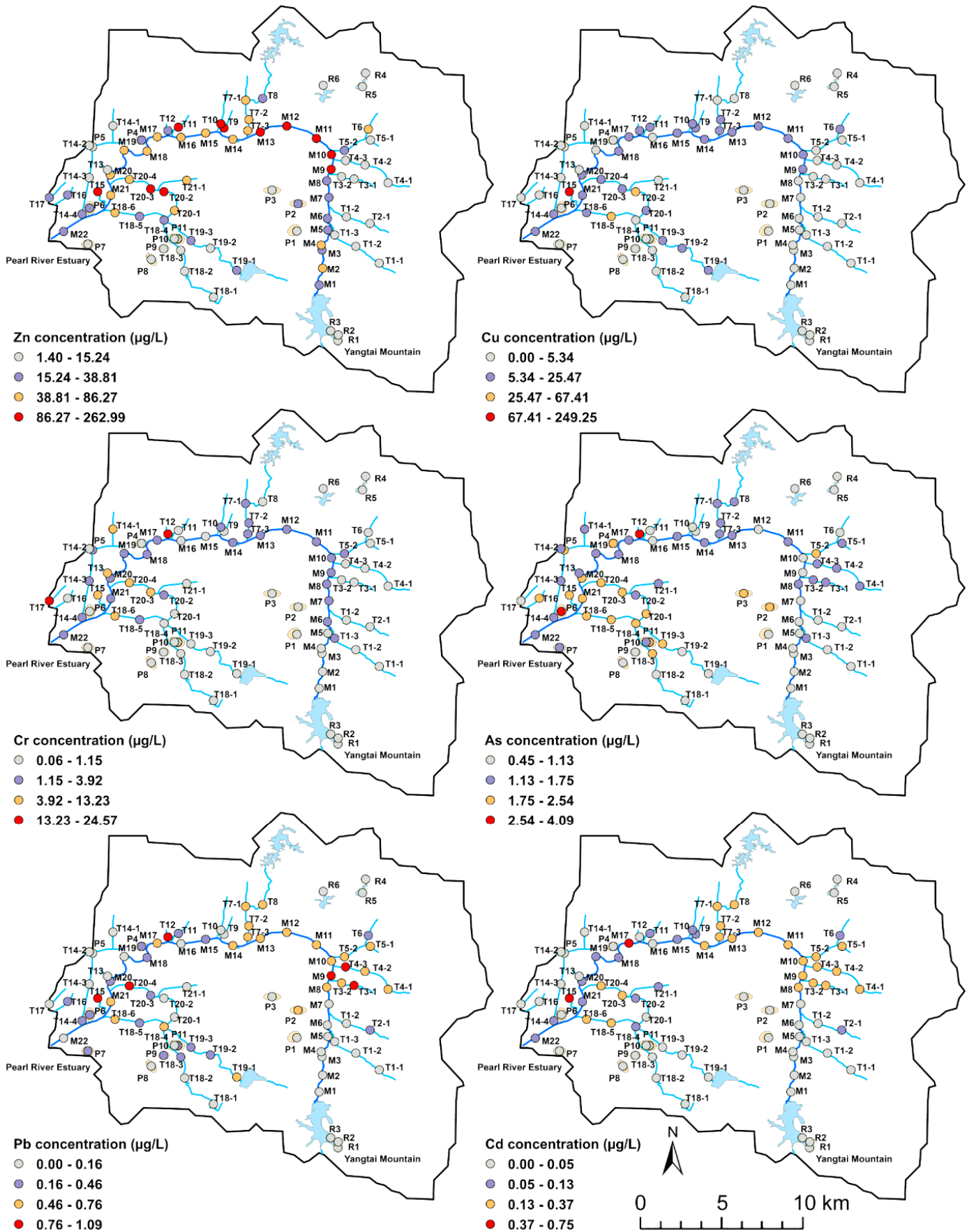

Figure 3. Watershed-scale spatial distribution of metal(loid) concentrations in the Maozhou River watershed. 

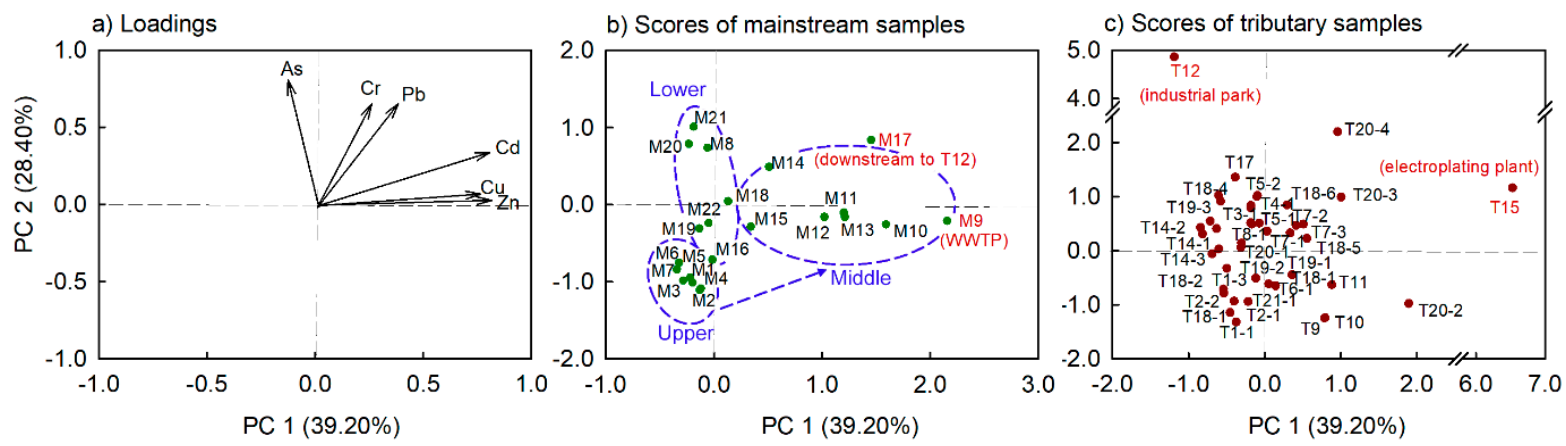

Figure 4. (a) Loading and (b,c) score plots of six dissolved metal(loid) concentrations in the mainstream and tributary samples of the Maozhou River based on principal component analysis (PCA).

Compared to the mainstream, the tributary showed much higher variations in the dissolved metal(loid) concentrations across the sampling sites (Figure 3). Although none of the tributary samples above M8 (i.e., T1-1, T1-2, T1-3, T2-1, and T2-2) had metal(loid) concentrations higher than the national standards, the highest metal(loid) concentrations within the whole river often occurred in tributaries (Figure 3). For example, the highest level of $\mathrm{Cu}$ was recorded at T15 $\left(249.25 \mu \mathrm{g} \cdot \mathrm{L}^{-1}\right)$, followed by that at T18 and T20. The highest level of Zn was found at T15 $\left(262.99 \mu \mathrm{g} \cdot \mathrm{L}^{-1}\right)$, followed by that at T20, T18, and M9. Likewise, the highest level of $\mathrm{Cr}$ was found at T17 $\left(24.57 \mu \mathrm{g} \cdot \mathrm{L}^{-1}\right)$ and that of As was at T12 $\left(4.09 \mu \mathrm{g} \cdot \mathrm{L}^{-1}\right)$. Based on the PCA scores, site T12 had the highest score on PC1, and site T15 had the highest score on PC2 (Figure 4c).

\subsection{Relationships between Dissolved Metal(loid) Concentrations and DOM Parameters}

The DOC, $\mathrm{UV}_{254}$, and Fmax values were used to indicate the abundances of bulk DOM, CDOM, and FDOM, respectively. Among all metal(loid) concentrations, the As concentration was consistently correlated with all proxies for bulk DOM, CDOM, and FDOM for the categories of all samples, the more disturbed mainstream and tributary samples, and the less disturbed pond and reservoir samples; additionally, the correlation coefficients were highest for the pond and reservoir category (Figure 5). In contrast, other dissolved metal(loid)s had different metal(loid) versus DOM correlations among the different sample categories. For all 84 samples, most dissolved metal(loid) concentrations were significantly correlated with DOC concentration or $\mathrm{UV}_{254}$ (Figure 5 and Table S2). In contrast, almost all metal(loid) concentrations were significantly correlated with Fmax $\operatorname{Cax}_{\mathrm{C} 3}$ and Fmax $\mathrm{C}_{\mathrm{C} 4}$ (except for the $\mathrm{Pb}$ concentration versus $\mathrm{Fmax}_{\mathrm{C} 3}$ ), and the $\mathrm{Zn}, \mathrm{Cu}$, and $\mathrm{Cr}$ concentrations were significantly correlated with $\mathrm{Fmax}_{\mathrm{C} 1}$ and $\mathrm{Fmax}_{\mathrm{C} 2}$. For the mainstream and tributary samples, the $\mathrm{Zn}$ and $\mathrm{Cu}$ concentrations were not significantly correlated with DOC concentration or $\mathrm{UV}_{254}$ but were significantly correlated with $\mathrm{Fmax}_{\mathrm{C} 3}$ and $\mathrm{Fmax}_{\mathrm{C} 4}$ (Figure 5 and Table S3). The $\mathrm{Cr}$ concentration was significantly correlated with DOC, $\mathrm{UV}_{254}, \mathrm{Fmax}_{\mathrm{C} 2}, \mathrm{Fmax}_{\mathrm{C} 3}$, and $\mathrm{Fmax}_{\mathrm{C} 4}$. In contrast, the $\mathrm{Pb}$ and $\mathrm{Cd}$ concentrations, which were the lowest among all six metal(loid)s, were not significantly correlated with any of the DOC concentrations, $\mathrm{UV}_{254}$, or Fmax values. For the less disturbed pond and reservoir samples, the $\mathrm{Zn}$ concentration was not significantly correlated with the DOC concentration, $\mathrm{UV}_{254}$, or Fmax values, and the $\mathrm{Cu}$ concentration correlated with only FmaxC4 (Figure 5 and Table S4). The Cr concentration was significantly and positively correlated with all proxies for bulk DOM, CDOM, and FDOM. The Pb and $\mathrm{Cd}$ concentrations were significantly and positively correlated with the DOC concentrations and Fmax $_{C 4}$ but not with the $\mathrm{UV}_{254}$. Overall, regardless of sample category (i.e., all samples, more disturbed samples, or less disturbed samples), the Fmax of the protein-like FDOM showed higher likelihood of being correlated with the dissolved metal(loid) concentrations than with the $\mathrm{UV}_{254}$ (proxy of CDOM) and Fmax of the humic-like FDOM (Figure 5). 


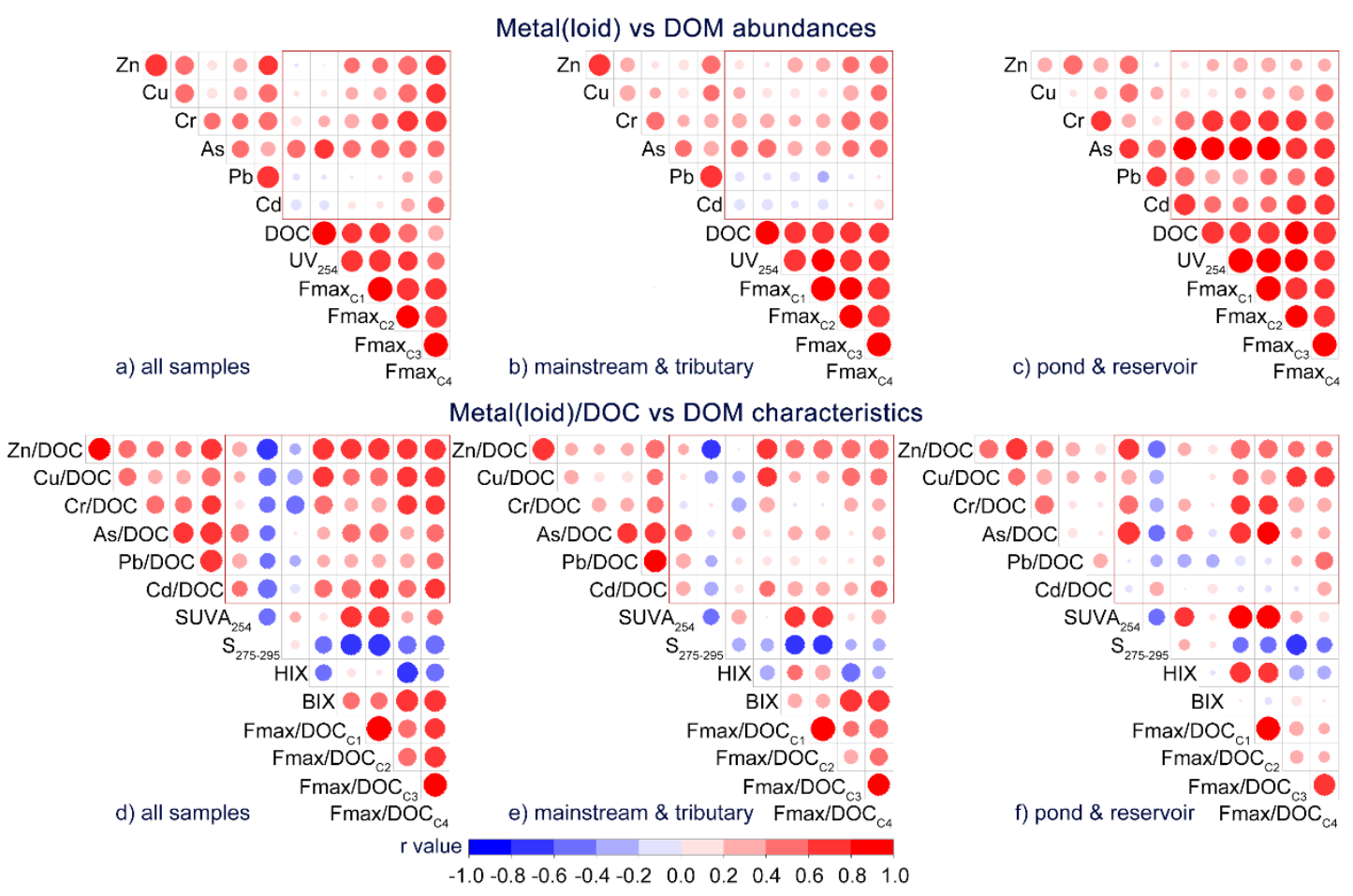

Figure 5. Correlation matrices between ( $\mathbf{a}-\mathbf{c}$ ) dissolved metal(loid) concentrations and abundances of bulk, chromophoric, and fluorescent dissolved organic matter (DOM) and (d-f) between metal(loid)s to dissolved organic carbon ratio (Me/DOC) and DOM characteristics. $\mathrm{UV}_{254}$, ultraviolet absorbance at $254 \mathrm{~nm}$; Fmax $\mathrm{C}_{\mathrm{i}}$, maximum fluorescence intensity for component i; $\mathrm{SUVA}_{254}$, specific ultraviolet absorbance at $254 \mathrm{~nm} ; \mathrm{S}_{275-295}$, absorbance slope between $275 \mathrm{~nm}$ and $295 \mathrm{~nm}$; HIX, humification index; BIX, biological index; Fmax/DOC $\mathrm{Ci}_{1}$, Fmax to DOC ratio of fluorescent component $i$.

The SUVA $254, \mathrm{~S}_{275-295}$, HIX, BIX, and Fmax/DOC values were used to indicate the DOM characteristics. For all 84 samples, the Me/DOC ratios were negatively correlated with the $\mathrm{S}_{275-295}$ and were positively correlated with the BIX and all the Fmax/DOC values. Although the Me/DOC ratios for $\mathrm{Zn}, \mathrm{As}, \mathrm{Pb}$, and $\mathrm{Cd}$ were positively correlated with the $\mathrm{SUVA}_{254}$, the $\mathrm{Cu} / \mathrm{DOC}$ and $\mathrm{Cr} / \mathrm{DOC}$ ratios did not have the same correlations. For the mainstream and tributary samples, the Me/DOC ratios for $\mathrm{As}, \mathrm{Pb}$, and $\mathrm{Cd}$ were correlated with the $\mathrm{SUVA}_{254}$, but those for $\mathrm{Zn}, \mathrm{Cu}$, and $\mathrm{Cr}$ were not. The $\mathrm{Zn} / \mathrm{DOC}, \mathrm{Cu} / \mathrm{DOC}$, and $\mathrm{Cd} / \mathrm{DOC}$ ratios were not correlated with the $\mathrm{S}_{275-295}$ but were significantly correlated with most fluorescence-related parameters, such as HIX, BIX, Fmax/DOC ${ }_{\mathrm{C} 2}$, Fmax/DOC $\mathrm{C}_{\mathrm{C} 3}$, and Fmax/DOC 4 . The $\mathrm{Cr} / \mathrm{DOC}$ and $\mathrm{As} / \mathrm{DOC}$ ratios were not correlated with the BIX but were positively correlated with some of the Fmax/DOC values. The $\mathrm{Pb} / \mathrm{DOC}$ ratio was correlated only with the $\mathrm{SUVA}_{254}$ but not with the other parameters. For the pond and reservoir samples, the Me/DOC ratios for $\mathrm{Zn}, \mathrm{Cr}$, and As were significantly correlated with the $\mathrm{SUVA}_{254}, \mathrm{Fmax} / \mathrm{DOC}_{\mathrm{C} 1}$, and Fmax/DOC $\mathrm{C}_{2}$, but those for $\mathrm{Cu}, \mathrm{Pb}$, and $\mathrm{Cd}$ were not. The $\mathrm{Cu} / \mathrm{DOC}$ ratio was correlated with only Fmax/DOC $\mathrm{C3}$ and Fmax/DOC $\mathrm{C}_{4}$, and the $\mathrm{Pb} / \mathrm{DOC}$ ratio was correlated with only Fmax/DOC $\mathrm{C}_{4}$. The $\mathrm{Cd} / \mathrm{DOC}$ ratio was not correlated with the $\mathrm{SUVA}_{254}, \mathrm{~S}_{275-295}$, HIX, BIX, or Fmax/DOC values.

\section{Discussion}

\subsection{Concentrations and Distribution of Dissolved Metal(loid)s}

Overall, the metal(loid) concentrations and synthetic pollution indices indicate that the pollution was higher in the mainstream and tributary river water than in the pond and reservoir water, and the Maozhou River was mainly polluted by $\mathrm{Zn}$ and $\mathrm{Cu}$. The particularly high $\mathrm{Zn}$ and $\mathrm{Cu}$ pollution at the mainstream sites, starting from $\mathrm{M} 9$, and the low $\mathrm{Zn}$ and $\mathrm{Cu}$ concentrations in the nearby tributaries and 
at M8 collectively indicate that the wastewater effluent at M9 was the major point source of $\mathrm{Cu}$ and $\mathrm{Zn}$ (Figure 3). This result agrees with the previous findings of high levels of dissolved $\mathrm{Cu}$ and $\mathrm{Zn}$ in sewage discharge $[30,31]$ and further supports that wastewater effluent is a considerable source of $\mathrm{Cu}$ and $\mathrm{Zn}$ pollution in urban rivers [4,54,55]. Note that the PC1 score of M9 (Figure 4b) was higher than those of all other mainstream sampling sites based on PCA, and this result supports the abovementioned impact of sewage discharge on $\mathrm{Cu}$ and $\mathrm{Zn}$ pollution. Compared to the metal(loid) concentrations in other urban rivers [49-52], the mainstream and tributary of the Maozhou River showed relatively high average concentrations of $\mathrm{Cu}$ and $\mathrm{Zn}$ (Table 1). Zn could be toxic to aquatic organisms at concentrations of tens to hundreds $\mu \mathrm{g} \cdot \mathrm{L}^{-1}$ depending on the organism species present [56]. Cu could be toxic to algae production (Chorella spp.) at 1-2 $\mu \mathrm{g} \cdot \mathrm{L}^{-1}$ [57] and acutely toxic to freshwater fish via the gills in soft water at low concentrations of $10-20 \mu \mathrm{g} \cdot \mathrm{L}^{-1}$ [58]. Therefore, the $\mathrm{Zn}$ and $\mathrm{Cu}$ pollution in the Maozhou River may contribute to the deterioration of environmental quality.

Although the other four metal(loid)s, i.e., $\mathrm{Cr}, \mathrm{As}, \mathrm{Pb}$, and $\mathrm{Cd}$, did not exceed the national standards, their concentrations in the middle and lower mainstream were elevated compared to those in the upper mainstream. Dissolved $\mathrm{Cr}$ in urban rivers can originate from discharge from electroplating and chemical plants as well as from road dust [1], and dissolved As can be derived from petrochemical facilities and fossil fuel combustion [59]. In addition to the background of soil parent material, other sources of $\mathrm{Cd}$ and $\mathrm{Pb}$ in urban environments usually are typically industrial sources such as automobile exhaust and tire wear [60]. There are several industrial parks around M8, and this manufacturing activity may have contributed to the relatively high $\mathrm{As}, \mathrm{Cd}$, and $\mathrm{Pb}$ found at the mainstream site $\mathrm{M} 8$ and the nearby tributary sites T3-1, T3-2, T4-1, T4-2, T4-3, and T5-2 (Figure 2). The metal(loid)-rich tributary inflow can contribute to the fluctuations in metal(loid) concentrations in the mainstream. For example, water from tributary site T12 (near an industrial park) with high $\mathrm{Cr}$, As, and Pb concentrations has been drained into site M17 and has caused sharp increases in the concentrations of these metal(loid)s in the mainstream. There are several industrial parks near the lower mainstream; these parks have electronics, leather, hardware factories, which are likely the main contributors to the high $\mathrm{Cr}$ and As concentrations found at mainstream sites M20 and M21 and the nearby tributary site T15.

\subsection{Relationships between Dissolved Metal(loid)s and DOM Abundances}

In the pond and reservoir samples, the dissolved $\mathrm{Cr}, \mathrm{As}, \mathrm{Pb}$, and $\mathrm{Cd}$ concentrations were all correlated with the DOC concentration. This result is in line with the commonly found correlations between dissolved metal(loid) concentrations and DOC concentrations in natural environments with little anthropogenic input and can be explained by the strong metal(loid)-DOM binding [15]. Specifically, the As concentration was significantly correlated with all proxies for bulk DOM, CDOM, and FDOM, regardless of the sample category. This result is consistent with previous results that DOM had a dramatic role in enhancing As mobility [61,62].

In contrast to the pond and reservoir samples, the correlations between metal(loid) and DOC concentrations were greatly weakened in the more disturbed mainstream and tributary river samples. Compared to the correlations between metal and DOC concentrations and between metal concentrations and $\mathrm{UV}_{254}$, the correlations between metal concentrations and Fmax ${ }_{\mathrm{C} 3}$ and Fmax $\mathrm{C}_{\mathrm{C} 4}$ were more likely to be significant. This result suggests that the protein-like FDOM and its correlated DOM components are an important pool affecting how DOM interacts with dissolved metal(loid)s in this black and odorous urban river. The specific metal(loid)-DOM complex found in various pollution sources and the increased metal(loid) affinity of the anthropogenic DOM composition explain the weakened metal(loid) versus DOM correlations and the relatively strong metal(loid) versus protein-like FDOM correlations. For example, wastewater effluents from WWTPs can contribute high loads of Zn, Cu, and their complexes with effluent organic matter to urban rivers [4,54,55]. The DOM impacted by WWTPs in urban river was found to have more protein-like, polysaccharide-like, and surfactant-like DOM components, with lower molecular size, aromaticity, and HIX, but higher FI and BIX than natural DOM $[28,33,34]$. In addition, two-dimensional correlation spectroscopy (2D-COS) analysis 
has previously indicated that the protein-like and polysaccharide-like organic matter had a higher susceptibility and preferential binding with $\mathrm{Cu}$ (II) than did humic-like substances [17]. Overall, our results highlight that in this black and odorous urban river, anthropogenic DOM such as protein-like FDOM play an important role in interacting with dissolved metal(loid)s.

\subsection{Relationships between Me/DOC and DOM Characteristics}

To minimize the interferences from variation in DOM levels, the metal(loid) affinity with DOM was assessed by the $\mathrm{Me} / \mathrm{DOC}$ ratios. The $\mathrm{Me} / \mathrm{DOC}$ ratio has been found to be significantly and positively correlated with the $\mathrm{SUVA}_{254}$, which is a proxy of DOM aromaticity [18]. This ratio is particularly valuable for $\mathrm{Cu}$ because more than $99 \%$ of dissolved $\mathrm{Cu}$ could be in the DOM-bound form based on the chemical equilibrium calculation [18]. This finding highlights the importance of DOM characteristics in regulating the interaction between metal(loid)s and DOM. However, in the present study, not all of the $\mathrm{Me} / \mathrm{DOC}$ ratios were correlated with the $\mathrm{SUVA}_{254}$. In particular, the $\mathrm{Cu} / \mathrm{DOC}$ ratio was not correlated with the $\mathrm{SUVA}_{254}$. This disconnection between $\mathrm{Cu} / \mathrm{DOC}$ and $\mathrm{SUVA}_{254}$ was possibly due to a strong anthropogenic input of less aromatic effluent organic matter, which had a strong affinity for $\mathrm{Cu}$. Other factors that can influence the complexation between metal(loid)s and aromatic DOM include water acidity and quality [18], anthropogenic influences [63], and metal(loid) speciation [10].

All Me/DOC ratios were negatively correlated with the $S_{275-295}$ and positively correlated with the BIX and Fmax/DOC values across all samples, highlighting the key role of DOM characteristics in the interactions of organic metal(loid) complexes [64]. Within the disturbed mainstream and tributary samples, the Me/DOC ratios for the major pollutants of $\mathrm{Zn}$ and $\mathrm{Cu}$ were correlated with the $\mathrm{S}_{275-295}$, $\mathrm{BIX}, \mathrm{Fmax} / \mathrm{DOC}_{\mathrm{C} 3}$, and Fmax/DOC $\mathrm{C}_{4}$. A low $\mathrm{S}_{275-295}$ is indicative of a high DOM molecular size, and a high BIX suggests high loads of fresh DOM [45,47]. Therefore, these correlations are consistent with findings in earlier studies [22,65] and suggest that the high-molecular-size and microbial-derived DOM strongly interact with dissolved metal(loid)s across all samples. The consistent positive correlations between the Me/DOC ratios and Fmax/DOC values imply that a higher proportion of both humic-like and protein-like FDOM in DOM can provide more binding sites for dissolved metal(loid)s across all samples. However, when only mainstream samples were considered, the $\mathrm{Me} / \mathrm{DOC}$ ratios were still positively correlated with the Fmax/DOC $\mathrm{C}_{3}$ and $\mathrm{Fmax} / \mathrm{DOC}_{\mathrm{C} 4}$ values but were negatively correlated with the Fmax/DOC $\mathrm{C}_{1}$ and Fmax/DOC $\mathrm{C}_{2}$ values (Supplementary Table S5). This phenomenon could be explained by the negative correlations between the Fmax/DOC for humic-like FDOM and the Fmax/DOC for protein-like FDOM within the mainstream samples. In other words, in the disturbed mainstream river, the anthropogenic protein-like proportion in DOM increased while the natural humic-like proportion decreased with increasing disturbance $[28,33]$. This phenomenon also implies that the dominant ligands for dissolved metal(loid)s in the mainstream could shift from natural sources (such as humic-like FDOM) to anthropogenic sources (such as protein-like FDOM from the WWTP).

\section{Conclusions}

Here, we investigated the concentrations of dissolved metal(loid)s and their relations with DOM-related parameters in the polluted Maozhou River watershed that is experiencing rapid urbanization. The main findings included the following:

(a) The mainstream and tributary water of the Maozhou River watershed was mainly contaminated by dissolved $\mathrm{Cu}$ and $\mathrm{Zn}$. Greater variations in the metal(loid) concentrations and their maximum concentrations were more often noted in tributaries than in the mainstream.

(b) Urbanization may weaken the correlations between dissolved metal(loid)s and DOM concentrations. Dissolved metal(loid) concentrations were more likely to be significantly correlated with the abundances of protein-like components of DOM than with the abundances of bulk DOM (DOC concentration) or CDOM $\left(\mathrm{UV}_{254}\right)$ in this black and odorous river. 
(c) The significant correlations between the Me/DOC for $\mathrm{Zn}$ or $\mathrm{Cu}$ and the $\mathrm{SUVA}_{254}$ found in a previous study were not found here. Rather, the Me/DOC for $\mathrm{Zn}$ or $\mathrm{Cu}$ had more significant correlations with fluorescence-based parameters such as the BIX and Fmax/DOC ratios.

Overall, this study provides first-hand watershed-scale information of metal(loid)-DOM relations in a representative black and odorous urban river. More recognitions of the seasonal variations in metal(loid)-DOM interactions and the binding mechanisms between heavy metal(loid)s and DOM should be resolved with more intensive monitoring and laboratory-based molecular-level analyses in the future.

Supplementary Materials: The following are available online at http://www.mdpi.com/2073-4441/12/1/281/s1, Figure S1: Four fluorescent dissolved organic matter (FDOM) components resolved by parallel factor analysis. Figure S2: The $\mathrm{pH}$ and electrical conductivity (EC) values of mainstream samples in Maozhou River. Figure S3: dissolved metal(loid) concentrations mainstream samples in Maozhou River. Figure S4: Correlations between $\mathrm{Cu}$ to DOC concentration ratio $(\mathrm{Cu} / \mathrm{DOC})$ and the dissolved organic matter characteristics. Table S1: The maximum fluorescence intensity of the four fluorescent dissolved organic matter (FDOM) components (in Raman Unit) of different water types in Maozhou River. Table S2: $P$ values of correlation analysis between dissolved metal(loid) concentrations and DOM parameters in all samples. Table S3: $P$ values of correlation analysis between dissolved metal(loid) concentrations and DOM parameters in the mainstream and tributary samples. Table S4: $P$ values of correlation analysis between dissolved metal(loid) concentrations and DOM parameters in the pond and reservoir samples. Table S5: $P$ values of correlation analysis between dissolved metal(loid) concentrations and DOM parameters in the mainstream samples. Table S6: $P$ values of correlation analysis between dissolved metal(loid) concentrations and DOM parameters in the tributary samples. Table S7: $P$ values of correlation analysis between dissolved metal(loid) concentrations and DOM parameters in the pond samples. Table S8: $P$ values of correlation analysis between dissolved metal(loid) concentrations and DOM parameters in the reservoir samples. Table S9: Dissolved organic carbon (DOC) concentrations and optical properties of dissolved organic matter for the mainstream, tributary, reservoir and pond water. Supplementary data related to this article are available online.

Author Contributions: C.C. and J.-J.W. were responsible for the original experimental design. Z.S., Z.-T.Z., Q.Y., and X.-W.C. conducted the experiments and gave valuable suggestions. S.Z. and J.-J.W. wrote the first draft. All authors contributed to the data interpretation and manuscript revision. All authors have read and agreed to the published version of the manuscript.

Funding: This research was funded by the Guangdong University Featured Innovation Project (2018KTSCX199), National Science Foundation of China (41807360 and 41761074), Natural Science Foundation of Guangdong Province (2014A030313720), and Science and Technology Project of Guangdong Province (2015A020215002).

Acknowledgments: We thank Yu-Chen Liu for his assistance on water sample collection.

Conflicts of Interest: The authors declare no conflict of interest.

\section{References}

1. $\quad$ Liang, B.; Han, G.L.; Liu, M.; Yang, K.H.; Li, X.Q.; Liu, J.K. Distribution, sources, and water quality assessment of dissolved heavy metals in the Jiulongjiang River water, southeast China. Int. J. Environ. Res. Public Health 2018, 15, 2752. [CrossRef]

2. Lourino-Cabana, B.; Lesven, L.; Billon, G.; Proix, N.; Recourt, P.; Ouddane, B.; Fischer, J.C.; Boughriet, A. Impacts of metal contamination in Calcareous Waters of Deûle River (France): Water quality and thermodynamic studies on metallic mobility. Water Air Soil Pollut. 2010, 206, 187-201. [CrossRef]

3. Sekabira, K.; Origa, H.O.; Basamba, T.A.; Mutumba, G.; Kakudidi, E. Assessment of heavy metal pollution in the urban stream sediments and its tributaries. Int. J. Environ. Sci. Technol. 2010, 7, 435-446. [CrossRef]

4. Mansoor, S.Z.; Louie, S.; Lima, A.T.; Van Cappellen, P.; MacVicar, B. The spatial and temporal distribution of metals in an urban stream: A case study of the Don River in Toronto, Canada. J. Gt. Lakes Res. 2018, 44, 1314-1326. [CrossRef]

5. Sun, X.; Crittenden, J.C.; Li, F.; Lu, Z.M.; Dou, X.L. Urban expansion simulation and the spatio-temporal changes of ecosystem services, a case study in Atlanta Metropolitan area, USA. Sci. Total Environ. 2018, 622, 974-987. [CrossRef] [PubMed]

6. Xia, W.L.; Chen, L.; Deng, X.W.; Liang, G.D.; Giesy, J.P.; Rao, Q.Y.; Wen, Z.H.; Wu, Y.; Chen, J.; Xie, P. Spatial and interspecies differences in concentrations of eight trace elements in wild freshwater fishes at different trophic levels from middle and eastern China. Sci. Total Environ. 2019, 672, 883-892. [CrossRef] [PubMed] 
7. De Lemos, C.T.; Iranco, F.D.; de Oliveira, N.C.D.; de Souza, G.D.; Fachel, J.M.G. Biomonitoring of genotoxicity using micronuclei assay in native population of Astyanax jacuhiensis (Characiformes: Characidae) at sites under petrochemical influence. Sci. Total Environ. 2008, 406, 337-343. [CrossRef] [PubMed]

8. Xu, L.; Wang, T.Y.; Ni, K.; Liu, S.J.; Wang, P.; Xie, S.W.; Meng, J.; Zheng, X.Q.; Lu, Y.L. Metals contamination along the watershed and estuarine areas of southern Bohai Sea, China. Mar. Pollut. Bull. 2013, 74, 453-463. [CrossRef]

9. Patel, P.; Raju, N.J.; Reddy, B.; Suresh, U.; Sankar, D.B.; Reddy, T.V.K. Heavy metal contamination in river water and sediments of the Swarnamukhi River Basin, India: Risk assessment and environmental implications. Environ. Geochem. Health 2018, 40, 609-623. [CrossRef]

10. Yan, M.Q.; Ma, J.; Zhang, C.Y.; Zhou, Y.X.; Liu, F.; Han, X.Z.; Li, M.Y.; Ni, J.R. Optical property of dissolved organic matters (DOMs) and its link to the presence of metal ions in surface freshwaters in China. Chemosphere 2017, 188, 502-509. [CrossRef]

11. Adusei-Gyamfi, J.; Ouddane, B.; Rietveld, L.; Cornard, J.P.; Criquet, J. Natural organic matter-cations complexation and its impact on water treatment: A critical review. Water Res. 2019, 160, 130-147. [CrossRef] [PubMed]

12. Hu, B.; Wang, P.F.; Wang, C.; Qian, J.; Hou, J.; Cui, X.A.; Zhang, N.N. The effect of anthropogenic impoundment on dissolved organic matter characteristics and copper binding affinity: Insights from fluorescence spectroscopy. Chemosphere 2017, 188, 424-433. [CrossRef] [PubMed]

13. Simon, C.; Osterholz, H.; Koschinsky, A.; Dittmar, T. Riverine mixing at the molecular scale-An ultrahigh-resolution mass spectrometry study on dissolved organic matter and selected metals in the Amazon confluence zone (Manaus, Brazil). Org. Geochem. 2019, 129, 45-62. [CrossRef]

14. Berto, S.; De Laurentiis, E.; Tota, T.; Chiavazza, E.; Daniele, P.G.; Minella, M.; Isaia, M.; Brigante, M.; Vione, D. Properties of the humic-like material arising from the photo-transformation of L-tyrosine. Sci. Total Environ. 2016, 545, 434-444. [CrossRef] [PubMed]

15. Baken, S.; Degryse, F.; Verheyen, L.; Merckx, R.; Smolders, E. Metal complexation properties of freshwater dissolved organic matter are explained by its aromaticity and by anthropogenic ligands. Environ. Sci. Technol. 2011, 45, 2584-2590. [CrossRef] [PubMed]

16. Guo, X.J.; He, X.S.; Li, C.W.; Li, N.X. The binding properties of copper and lead onto compost-derived DOM using Fourier-transform infrared, UV-vis and fluorescence spectra combined with two-dimensional correlation analysis. J. Hazard. Mater. 2019, 365, 457-466. [CrossRef]

17. Huang, M.; Li, Z.W.; Luo, N.L.; Yang, R.; Wen, J.J.; Huang, B.; Zeng, G.M. Application potential of biochar in environment: Insight from degradation of biochar-derived DOM and complexation of DOM with heavy metals. Sci. Total Environ. 2019, 646, 220-228. [CrossRef]

18. Kikuchi, T.; Fujii, M.; Terao, K.; Jiwei, R.; Lee, Y.P.; Yoshimura, C. Correlations between aromaticity of dissolved organic matter and trace metal concentrations in natural and effluent waters: A case study in the Sagami River Basin, Japan. Sci. Total Environ. 2017, 576, 36-45. [CrossRef]

19. Lavoie, R.A.; Amyot, M.; Lapierre, J.F. Global meta-analysis on the relationship between mercury and dissolved organic carbon in freshwater environments. J. Geophys. Res. Biogeosci. 2019, 124, 1508-1523. [CrossRef]

20. Wong, K.H.; Obata, H.; Kim, T.; Wakuta, Y.; Takeda, S. Distribution and speciation of copper and its relationship with FDOM in the East China Sea. Mar. Chem. 2019, 212, 96-107. [CrossRef]

21. Fujii, M.; Imaoka, A.; Yoshimura, C.; Waite, T.D. Effects of Molecular Composition of Natural Organic Matter on Ferric Iron Complexation at Circumneutral pH. Environ. Sci. Technol. 2014, 48, 4414-4424. [CrossRef] [PubMed]

22. Xu, H.C.; Guan, D.X.; Zou, L.; Lin, H.; Guo, L.D. Contrasting effects of photochemical and microbial degradation on $\mathrm{Cu}(\mathrm{II})$ binding with fluorescent DOM from different origins. Environ. Pollut. 2018, 239, 205-214. [CrossRef] [PubMed]

23. Chen, W.B.; Smith, D.S.; Gueguen, C. Influence of water chemistry and dissolved organic matter (DOM) molecular size on copper and mercury binding determined by multiresponse fluorescence quenching. Chemosphere 2013, 92, 351-359. [CrossRef] [PubMed]

24. Kinniburgh, D.G.; van Riemsdijk, W.H.; Koopal, L.K.; Borkovec, M.; Benedetti, M.F.; Avena, M.J. Ion binding to natural organic matter: Competition, heterogeneity, stoichiometry and thermodynamic consistency. Colloid Surf. A Physicochem. Eng. Asp. 1999, 151, 147-166. [CrossRef] 
25. Cabaniss, S.E. Forward Modeling of Metal Complexation by NOM: II. Prediction of Binding Site Properties. Environ. Sci. Technol. 2011, 45, 3202-3209. [CrossRef] [PubMed]

26. Shenzhen Water Goup 2016. Disclosure of Environmental Information. Available online: https://www.szwater.com.cn/environmentpolicy (accessed on 10 September 2019).

27. Redman, A.D.; Macalady, D.L.; Ahmann, D. Natural organic matter affects arsenic speciation and sorption onto hematite. Environ. Sci. Technol. 2002, 36, 2889-2896. [CrossRef]

28. Ye, Q.H.; Zhang, Z.T.; Liu, Y.C.; Wang, Y.H.; Zhang, S.; He, C.; Shi, Q.; Zeng, H.X.; Wang, J.J. Spectroscopic and molecular-level characteristics of dissolved organic matter in a highly polluted urban river in south China. ACS Earth Space Chem. 2019, 3, 2033-2044. [CrossRef]

29. He, D.; He, C.; Li, P.H.; Zhang, X.W.; Shi, Q.; Sun, Y.G. Optical and molecular signatures of dissolved organic matter reflect anthropogenic influence in a Coastal River, northeast China. J. Environ. Qual. 2019, 48, 603-613. [CrossRef]

30. Chaminda, G.G.T.; Nakajima, F.; Furumai, H.; Kasuga, I.; Kurisu, F. Comparison of metal (Zn and Cu) complexation characteristics of DOM in urban runoff, domestic wastewater and secondary effluent. Water Sci. Technol. 2010, 62, 2044-2050. [CrossRef]

31. Wang, N.; Wang, X.C.C.; Liu, H.L.; Zheng, Y.C.; Zhang, Y.; Xiong, J.Q.; Pan, P.; Liu, Y.Z. Speciation, distribution and risk assessment of metals in sediments from a water body replenished by effluent from a wastewater treatment plant. Bull. Environ. Contam. Toxicol. 2019, 102, 525-530. [CrossRef]

32. Wu, F.C.; Evans, D.; Dillon, P.; Schiff, S. Molecular size distribution characteristics of the metal-DOM complexes in stream waters by high-performance size-exclusion chromatography (HPSEC) and high-resolution inductively coupled plasma mass spectrometry (ICP-MS). J. Anal. At. Spectrom. 2004, 19, 979-983. [CrossRef]

33. Liu, Q.; Jiang, Y.; Tian, Y.L.; Hou, Z.J.; He, K.J.; Fu, L.; Xu, H. Impact of land use on the DOM composition in different seasons in a subtropical river flowing through a region undergoing rapid urbanization. J. Clean Prod. 2019, 212, 1224-1231. [CrossRef]

34. Liang, M.-Q.; Shao, M.-L.; Cao, C.-L.; Zong, Y.-N.; Tang, J.-F. Characteristics of dissolved organic matter $(\mathrm{DOM})$ and relationship with dissolved heavy metals in a peri-urban and an urban river. Huan jing ke $x u e=$ Huanjing kexue 2018, 39, 2095-2103. [PubMed]

35. Zhang, D.; Wang, J.J.; Ni, H.G.; Zeng, H. Spatial-temporal and multi-media variations of polycyclic aromatic hydrocarbons in a highly urbanized river from South China. Sci. Total Environ. 2017, 581, 621-628. [CrossRef]

36. Qiu, W.H.; Sun, J.; Fang, M.J.; Luo, S.S.; Tian, Y.Q.; Dong, P.Y.; Xu, B.T.; Zheng, C.M. Occurrence of antibiotics in the main rivers of Shenzhen, China: Association with antibiotic resistance genes and microbial community. Sci. Total Environ. 2019, 653, 334-341. [CrossRef]

37. Yu, K.; Duan, Y.; Liao, P.; Xie, L.; Li, Q.; Ning, Z.; Liu, C. Watershed-scale distributions of heavy metals in the hyporheic zones of a heavily polluted Maozhou River watershed, southern China. Chemosphere 2019, 239, 124773. [CrossRef]

38. Liao, H.H.; Yu, K.; Duan, Y.H.; Ning, Z.G.; Li, B.R.; He, L.Y.; Liu, C.X. Profiling microbial communities in a watershed undergoing intensive anthropogenic activities. Sci. Total Environ. 2019, 647, 1137-1147. [CrossRef]

39. Cao, C.; Chen, X.P.; Ma, Z.B.; Jia, H.H.; Wang, J.J. Greenhouse cultivationmitigates metal-ingestion-associated health risks from vegetables in wastewater-irrigated agroecosystems. Sci. Total Environ. 2016, 560, $204-211$. [CrossRef]

40. Fellman, J.B.; Hood, E.; Spencer, R.G.M. Fluorescence spectroscopy opens new windows into dissolved organic matter dynamics in freshwater ecosystems: A review. Limnol. Oceanogr. 2010, 55, 2452-2462. [CrossRef]

41. Korak, J.A.; Wert, E.C.; Rosario-Ortiz, F.L. Evaluating fluorescence spectroscopy as a tool to characterize cyanobacteria intracellular organic matter upon simulated release and oxidation in natural water. Water Res. 2015, 68, 432-443. [CrossRef]

42. Birdwell, J.E.; Engel, A.S. Characterization of dissolved organic matter in cave and spring waters using UV-Vis absorbance and fluorescence spectroscopy. Org. Geochem. 2010, 41, 270-280. [CrossRef]

43. Tank, S.E.; Lesack, L.F.W.; Gareis, J.A.L.; Osburn, C.L.; Hesslein, R.H. Multiple tracers demonstrate distinct sources of dissolved organic matter to lakes of the Mackenzie Delta, western Canadian Arctic. Limnol. Oceanogr. 2011, 56, 1297-1309. [CrossRef] 
44. Weishaar, J.L.; Aiken, G.R.; Bergamaschi, B.A.; Fram, M.S.; Fujii, R.; Mopper, K. Evaluation of specific ultraviolet absorbance as an indicator of the chemical composition and reactivity of dissolved organic carbon. Environ. Sci. Technol. 2003, 37, 4702-4708. [CrossRef] [PubMed]

45. Helms, J.R.; Stubbins, A.; Ritchie, J.D.; Minor, E.C.; Kieber, D.J.; Mopper, K. Absorption spectral slopes and slope ratios as indicators of molecular weight, source, and photobleaching of chromophoric dissolved organic matter. Limnol. Oceanogr. 2008, 53, 955-969. [CrossRef]

46. Ohno, T. Fluorescence inner-filtering correction for determining the humification index of dissolved organic matter. Environ. Sci. Technol. 2002, 36, 742-746. [CrossRef]

47. Wilson, H.F.; Xenopoulos, M.A. Effects of agricultural land use on the composition of fluvial dissolved organic matter. Nat. Geosci. 2009, 2, 37-41. [CrossRef]

48. State Environmental Protection Administration. Environmental Quality Standard of Surface Water GB 3838-2002; State Environmental Protection Administration: Beijing, China, 2002.

49. Harguinteguy, C.A.; Gudino, G.L.; Aran, D.S.; Pignata, M.L.; Fernandez-Cirelli, A. Comparison between two submerged macrophytes as biomonitors of trace elements related to anthropogenic activities in the ctalamochita river, argentina. Bull. Environ. Contam. Toxicol. 2019, 102, 105-114. [CrossRef]

50. Leventeli, Y.; Yalcin, F.; Kilic, M. An investigation about heavy metal pollution of duden and goksu streams (Antalya, Turkey). Appl. Ecol. Environ. Res. 2019, 17, 2423-2436. [CrossRef]

51. Islam, M.S.; Ahmed, M.K.; Raknuzzaman, M.; Habibullah-Al-Mamun, M.; Islam, M.K. Heavy metal pollution in surface water and sediment: A preliminary assessment of an urban river in a developing country. Ecol. Indic. 2015, 48, 282-291. [CrossRef]

52. Le Pape, P.; Ayrault, S.; Quantin, C. Trace element behavior and partition versus urbanization gradient in an urban river (Orge River, France). J. Hydrol. 2012, 472, 99-110. [CrossRef]

53. Li, S.Y.; Zhang, Q.F. Spatial characterization of dissolved trace elements and heavy metals in the upper Han River (China) using multivariate statistical techniques. J. Hazard. Mater. 2010, 176, 579-588. [CrossRef] [PubMed]

54. Elbaz-Poulichet, F.; Seidel, J.L.; Casiot, C.; Tusseau-Vuillemin, M.H. Short-term variability of dissolved trace element concentrations in the Marne and Seine Rivers near Paris. Sci. Total Environ. 2006, 367, 278-287. [CrossRef] [PubMed]

55. Nguyen, K.T.; Nguyen, H.M.; Truong, C.K.; Ahmed, M.B.; Huang, Y.; Zhou, J.L. Chemical and microbiological risk assessment of urban river water quality in Vietnam. Environ. Geochem. Health 2019, 41, 2559-2575. [CrossRef] [PubMed]

56. Siddiqui, E.; Verma, K.; Pandey, U.; Pandey, J. Metal Contamination in Seven Tributaries of the Ganga River and Assessment of Human Health Risk from Fish Consumption. Arch. Environ. Contam. Toxicol. 2019, 77, 263-278. [CrossRef]

57. Franklin, N.M.; Stauber, J.L.; Lim, R.P.; Petocz, P. Toxicity of metal mixtures to a tropical freshwater alga (Chlorella sp): The effect of interactions between copper, cadmium, and zinc on metal cell binding and uptake. Environ. Toxicol. Chem. 2002, 21, 2412-2422. [CrossRef]

58. Woody, C.A.; O'Neal, S. Effects of Copper on Fish and Aquatic Resources; Fisheries Research and Consulting: Alaska, AK, USA, 2012; Available online: https://www.conservationgateway.org/ConservationByGeography/ NorthAmerica/UnitedStates/alaska/sw/cpa/Documents/W2013ECopperF062012.pdf (accessed on 10 September 2019).

59. Gan, Y.D.; Huang, X.M.; Li, S.S.; Liu, N.; Li, Y.C.C.; Freidenreich, A.; Wang, W.X.; Wang, R.Q.; Dai, J.L. Source quantification and potential risk of mercury, cadmium, arsenic, lead, and chromium in farmland soils of Yellow River Delta. J. Clean Prod. 2019, 221, 98-107. [CrossRef]

60. Feng, J.J.; Chen, X.L.; Jia, L.; Liu, Q.Z.; Chen, X.J.; Han, D.M.; Cheng, J.P. Effluent concentration and removal efficiency of nine heavy metals in secondary treatment plants in Shanghai, China. Environ. Sci. Pollut. Res. 2018, 25, 17058-17065. [CrossRef]

61. Islam, F.S.; Gault, A.G.; Boothman, C.; Polya, D.A.; Charnock, J.M.; Chatterjee, D.; Lloyd, J.R. Role of metal-reducing bacteria in arsenic release from Bengal delta sediments. Nature 2004, 430, 68-71. [CrossRef]

62. Mladenov, N.; Zheng, Y.; Simone, B.; Bilinski, T.M.; McKnight, D.M.; Nemergut, D.; Radloff, K.A.; Rahman, M.M.; Ahmed, K.M. Dissolved organic matter quality in a shallow aquifer of bangladesh: Implications for arsenic mobility. Environ. Sci. Technol. 2015, 49, 10815-10824. [CrossRef] 
63. Kozyatnyk, I.; Bouchet, S.; Bjorn, E.; Haglund, P. Fractionation and size-distribution of metal and metalloid contaminants in a polluted groundwater rich in dissolved organic matter. J. Hazard. Mater. 2016, 318, 194-202. [CrossRef]

64. Warren, L.A.; Haack, E.A. Biogeochemical controls on metal behaviour in freshwater environments. Earth-Sci. Rev. 2001, 54, 261-320. [CrossRef]

65. Wu, J.; Zhang, H.; Shao, L.M.; He, P.J. Fluorescent characteristics and metal binding properties of individual molecular weight fractions in municipal solid waste leachate. Environ. Pollut. 2012, 162, 63-71. [CrossRef] [PubMed]

(C) 2020 by the authors. Licensee MDPI, Basel, Switzerland. This article is an open access article distributed under the terms and conditions of the Creative Commons Attribution (CC BY) license (http://creativecommons.org/licenses/by/4.0/). 